\title{
Early Growth Response of Hararghe Coffee Selections to Soil Moisture Deficit at Seedling Stage at Mechara, Eastern Ethiopia
}

\author{
Adisu Wegari", Mohammedsani Amin \\ Oromia Agricultural Research Institute, Mechara Agricultural Research Centre, Coffee and Tea Research Process, Ethiopia
}

Received May 22, 2020; Revised September 23, 2020; Accepted October 19, 2020

\section{Cite This Paper in the following Citation Styles}

(a): [1] Adisu Wegari, Mohammedsani Amin, "Early Growth Response of Hararghe Coffee Selections to Soil Moisture Deficit at Seedling Stage at Mechara, Eastern Ethiopia," Universal Journal of Agricultural Research, Vol. 8, No. 6, pp. 223 - 232, 2020. DOI: 10.13189/ujar.2020.080603.

(b): Adisu Wegari, Mohammedsani Amin (2020). Early Growth Response of Hararghe Coffee Selections to Soil Moisture Deficit at Seedling Stage at Mechara, Eastern Ethiopia. Universal Journal of Agricultural Research, 8(6), 223 - 232. DOI: 10.13189/ujar.2020.080603.

Copyright $\bigcirc 2020$ by authors, all rights reserved. Authors agree that this article remains permanently open access under the terms of the Creative Commons Attribution License 4.0 International License

\begin{abstract}
Drought is among the major factors that adversely affect coffee production in most parts of Ethiopia. Hararghe coffee is despite its economic importance in the world market and in the national economy of the country; its productivity is very low primarily because of periodic soil moisture deficit stresses and many other factors. Therefore, this experiment was conducted to screen and evaluate Hararghe coffee genotypes for drought tolerant in response to soil moisture stresses. A total of nineteen coffee genotypes; fourteen promising coffee selections and five released varieties were evaluated for morphological and physiological drought stress traits using Completely Randomized Design with three replications. The experiment was conducted at Mechara Agricultural Research Center in a rain shelter. Eight pairs of true leaf coffee seedlings were subjected to two watering regimes (water-stress by withholding irrigation and well-watered control). The analysis of variance results revealed significant variation among coffee genotypes for water deficit stress. Therefore, based on preliminary observations and visual assessments of recovery plants, the genotypes were grouped into three categories of drought tolerance; sensitive, moderately sensitive and relatively tolerant. However, genotypes from each category should also be tested for their morphological, physiological and biochemical responses to drought in order to identify more tolerant types and come up with a recommendation for further selection and
\end{abstract}

breeding works for drier coffee growing areas of the country.

Keywords Drought Tolerance, Leaf Shed, Moisture Deficit, Recovery Rate, Stress Score, Survival Rate

\section{Introduction}

Drought is an environmental factor that causes water deficit or water stress in plants (Pinheiro et al., 2005). Overall, drought and unfavorable temperatures are the major climatic limitations for coffee production (Da Matta and Ramalho 2006). These limitations are expected to become increasingly important in several coffee growing regions due to the recognized changes in global climate and also because coffee cultivation has spread towards marginal lands, where water shortage and unfavorable temperatures constitute major constraints to coffee yield (Da Matta and Ramalho 2006; Kimemia, 2010). The plants are frequently subjected to periods of water stress, which ultimately leads to reduced growth and productivity by affecting various physiological and biochemical processes. However, they have evolved different strategies to cope with water deficits through avoidance or postponement of dehydration or stress tolerance (Levitt, 1980; Turner, 1990; Pugnaire et al., 1999). In line with 
this, there exist variations among species or between genotypes within a species for acquiring different physiological, morphological and biochemical strategies for survival and even maintenance of some growth and physiological processes under stressful conditions (Levitt, 1980; Kozlowski and Pallardy, 1997; Joshi, 1999). Hence, these adaptive responses are not universal properties of plants (Nambiar et al., 1982; Volkmar and Woodbury, 1995) and could be used as selection criteria during screening genotypes for drought tolerance (Sanchez et al., 1998; Tesfaye, 2005; Tesfaye and Ismail, 2008, Tesfaye et al., 2013).

Understanding the genetic and physiological bases of drought tolerance in crop plants is necessary for developing drought tolerant genotypes through conventional breeding. In this regard, some works has been conducted on different crops for morphological and physiological bases of drought tolerant mechanisms. It has been reported that differences in mean rate of stress development (leaf folding or degree of wilting) is commonly used as an important criteria during screening of genotypes for drought tolerance (Cutler et al., 1980; Sloane et al., 1990; Rosario et al., 1992; Lilley and Fukai, 1994). Such a leaf movement, an adjustment of leaf angle or modification of leaf orientation to reduce the interception of solar radiation and, thus, decrease leaf temperature and water loss by transpiration is regarded as one of the drought avoidance mechanisms evolved in plants (Levitt, 1980; Ludlow and Muchow, 1990; Pugnaire et al., 1999; Carr, 2001). On the other hand, lower rate of stress development (less wilting symptom and gradual leaf rolling or folding) as a result of maintenance of turgor has been used as an important criteria during screening different crop genotypes for drought tolerance (Rosario et al., 1992; Sloane et al., 1990; Carter and Rufty, 1992; Cutler et al., 1980; De Datta et al., 1988; Price et al., 1992; Lilley and Fukai, 1994). Similarly, stay-green under water stress conditions has also been used as one of the traits to select corn varieties for drought tolerance (Kitbamroong and Chantachume, 1992).

Like other crop plants, Arabica coffee is sensitive to water stress and its growth and yield potential is greatly affected by seasonal drought. Despite its economic importance in the world market and in the national economy of some developing countries like Ethiopia, productivity of the crop is very low primarily because of periodic water deficit stresses (Rena et al., 1994; Barros et al., 1997; Carr, 2001; Tesfaye, 2005; Tesfaye et al., 2013). In fact, a number of authors, including Melaku (1982), Yacob et al. (1996) and Kassahun et al. (2008), have reported the existence of a large diversity among the genotypes of Arabica coffee with regard to yield potential, disease resistance and adaptation to different growth conditions in its center of origin, Ethiopia. However, the variability has not been studied and documented in relation to drought tolerance. The combined effects of this phenomenon have critical impacts on coffee production.

Hararghe coffee is despite its economic importance in the world market and in the national economy of Ethiopia; its productivity is very low primarily because of periodic soil moisture deficit stresses and many other factors. Despite these facts, there has been little work to examine the extent and pattern of responses of various $C$. arabica genotypes to water deficit in Ethiopia. Furthermore, the Mechara Agricultural Research Center in collaboration with Jimma Agricultural Research Center has been released four Hararghe coffee varieties through selection from large 1998 Hararghe coffee germplasm collections without further study in their relation to drought tolerance. Thus, this study was conducted for the objective to identify drought tolerant genotypes in response to soil moisture stress by testing their morphological and physiological traits that contribute to genotypes' differences for further breeding program in the study areas.

\section{Materials and Methods}

\subsection{Experimental Area}

An experiment was carried out at Mechara Agricultural Research Center (McARC) in eastern Oromia. The center is geographically located at altitude of 1760 m.a.s.l and receives an average annual rainfall of about $900 \mathrm{~mm}$ with monthly mean maximum and minimum temperatures of $26^{\circ} \mathrm{C}$ and $14^{\circ} \mathrm{C}$, respectively.

\subsection{Experimental Materials}

Ten promising Hararghe coffee selections (H-981/98; H-980/98; H-622/98; H-618/98; H-858/98; H-856/98; H-929/98; H-915/98; H-822/98; H-968/98) and four released varieties by McARC (Arusa; Bultum; Mechara-1 and Mocha) were used and one released variety (74110) which is high yielding, CBD resistance and widely adaptable, was also included as a check in the study. Seeds of those genotypes were collected from the mother tree planted in 2005 for variety verification plot in the field at Mechara ARC. The seedlings of each genotype were raised in polythene tube on standard coffee nursery with full management practices as per recommendation.

\section{Experimental Procedures and Design}

Seven months old and eight true leaves stage of uniform and healthy grown coffee seedlings from each coffee genotypes were selected and transferred to a rain shelter in plastic bucket of 51 capacity. The seedlings were uniformly managed to ensure maximum rate of their establishment for a month. The genotypes were tested for 
their responses to soil water deficit in a CRD design with three replications in two levels (well-watered and water stressed) of watering regime.

\section{Treatment Arrangement}

For making treatment combination, each genotype was subjected to two watering levels (well- watered as a control and water stressed by withholding watering). Each genotype plot contained a total of 12 coffee seedlings, six (6) seedlings per watering level. In order to make their uniform and full establishment, the seedlings of each genotype and watering level were uniformly managed for 30 days. After a month of establishment period, the seedlings were subjected to the respective watering treatment for 21 days and then, two seedlings from each plot were used to measure destructive parameters, while four seedlings in each water-stressed plot were re-watered for three weeks to determine the rate of recovery of each genotype.

\section{Data Collected}

\section{The following morphological and physiological data was collected:}

Stress scoring: Sensitivity of coffee genotypes to soil moisture deficit was assessed visually at two days intervals since the first wilting symptom was observed (after seven days). The degree of leaf folding or wilting was scored at morning (7:00 - 8.00 am) and noon (12:00-1:00 pm) hours, using 1 to 5 scoring scales (Figure 1); 1 indicating all leaves green and turgid, 2: most leaves still turgid except the youngest which show leaf folding, 3 : all leaves wilt and/or show leaf folding (symptoms of senescence evident), 4: most leaves (specially the older ones) turning pale green and showing severe wilting or folding and 5: all leaves turning brown and dry, mostly drooping (Rosario et al., 1992).

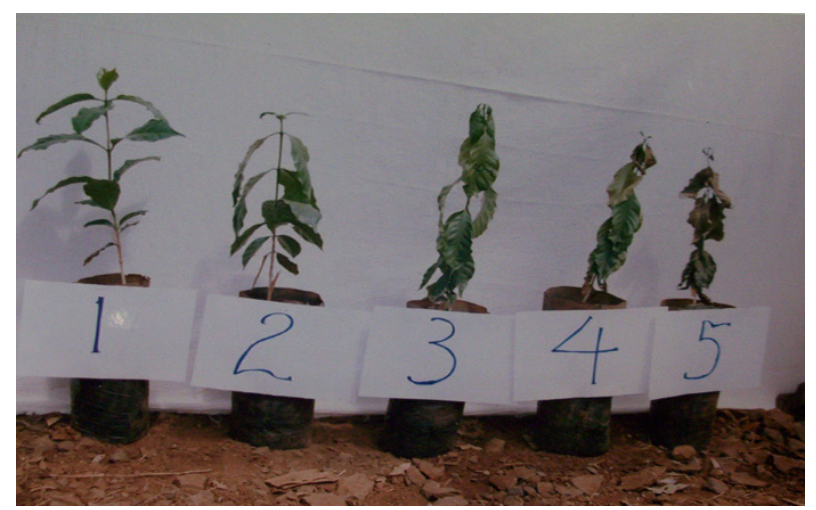

Figure 1. Method of stress scoring and the corresponding 1-5 scale score values for visual assessment and screening Arabica coffee genotypes for drought tolerance in a rain shelter

Non-Destructive Growth Parameters: plant height, number of leaves, leaves area; stem girth, growth rate, and number of wilted seedlings and percentage of rolled leaves were recorded from two seedlings in the central part of each plot. Leaf area was calculated using the method developed by Yakob et al. (1993) as follows:

$$
\mathrm{LA}=\mathrm{L} \times \mathrm{B} \times \mathrm{K}
$$

Where; LA $=$ Leaf area $\left(\mathrm{cm}^{2}\right), \mathrm{L}=$ Leaf length $(\mathrm{cm}), \mathrm{B}$ $=$ Maximum leaf breadth $(\mathrm{cm})$ and $\mathrm{K}=$ Correction factor $=0.7$

Destructive growth parameters: destructive plant growth parameters such tap root length $(\mathrm{cm})$ and root volume ( $\mathrm{ml}$ were recorded by uprooting two randomly selected seedlings from the central rows of each plot. Root volume of the selected seedlings was measured using displacement method (volume of water displaced by roots of a plant when the whole root system below the collar level is submerged in a $500 \mathrm{ml}$ graduated cylinder filled with $300 \mathrm{ml}$ tap water) immediately after harvesting and careful washing to remove all soil particles.

\section{Recovery Rate:}

After 21 days of water stressed seedlings in the stressed plots were re-watered at two days interval for three weeks and the number of dead plants and number of plants producing new growths (flushes of buds and new leaves). Survival rate, rate of leaf shade, or died were counted to estimate genotypic differences in rate of recovery from the soil drying or water stress treatment. Rate of survival was determined 15 days after frequent re-watering by counting the number of alive and dead plants per plot, while extent of leaf shedding was calculated based on the average number of leaves maintained by plants prior to and at the end of the water stress treatment.

\section{Physiological parameters:}

Three leaves were detached from the plant and immediately weight of each leaf was taken to get fresh weight (FW), each leaf was soaked in distilled water in the bucket and kept in bucket at $5^{\circ} \mathrm{C}$ for 24 hours and re-weighed to get turgid weight/saturated (TW) and finally oven dried at $70^{\circ} \mathrm{C}$ for 24 hours and weighed to get the dry weight (DW). Relative water content of leaf (RWCL) was calculated using the following formula:

$$
\text { RWCL }=\frac{(F W-D W)}{(T W-D W)} \times 100
$$

Leaf thickness (LT) was calculated as leaf dry weight divided by leaf area ( $\mathrm{LT}=\mathrm{Wd} / \mathrm{LA}$ ) (Bowyer and Danson, 2004).

\section{Specific leaf area (SLA)}

$$
\mathrm{SLA}=\frac{\mathrm{LA}}{\mathrm{LDW}}
$$


Where: SLA $=$ Specific leaf area; LA = Leaf area; LDW $=$ Leaf dry weight

\section{Data Analysis}

The collected data were statistically analyzed using GenStat software $15^{\text {th }}$ edition and whenever the ANOVA shows a significant difference between means Fisher's Protected Least Significant Difference was performed.

\section{Results and Discussion}

\section{Stress Scoring}

The analysis of variation shows that there was a significant difference observed among the genotype for the mean stress score (Table 1). About seven coffee genotypes; H-968/98, H-980/98, H-822/98, H-739/98, H-674/98, H-929/98, and H-915/98 were significantly sensitive to soil moisture deficit for the stress period of 21 days. However, the lower stress score values for rate of leaf folding (wilting) was recorded from H-981/98, H-858/98, H-856/98, H-622/98, H-823/98 and H-618/98 genotypes (Table 1). Furthermore, H-981/98 coffee genotype had significantly low stress value in the morning (Figure 2) and noon (Figure 3) under both well-watered and water stress condition. The significant difference observed among Hararghe coffee genotypes for soil moisture deficit is good indicator for the existence of exploitable genetic variability for the improvement of the genotypes.

Table 1. Mean stress score values for coffee genotypes under water-stressed (WS) condition on different days from start of treatment application till 21 days

\begin{tabular}{|c|c|c|c|c|c|c|}
\hline \multirow{2}{*}{ Genotypes } & \multicolumn{5}{|c|}{ Days from start of treatment } & \multirow{2}{*}{ Mean } \\
\hline & Day 8 & Day 11 & Day 14 & Day 17 & Day 20 & \\
\hline H-618/98 & 1.13 & 1.41 & 1.87 & 2.15 & 3.09 & 1.93 \\
\hline H-622/98 & 1.14 & 1.56 & 1.95 & 2.29 & 3.02 & 1.99 \\
\hline H-674/98 & 1.61 & 1.68 & 2.23 & 2.30 & 3.61 & 2.29 \\
\hline H-739/98 & 1.28 & 1.66 & 1.93 & 2.53 & 3.65 & 2.21 \\
\hline H-822/98 & 1.23 & 1.67 & 2.26 & 2.58 & 3.78 & 2.30 \\
\hline H-823/98 & 1.05 & 1.53 & 1.87 & 2.13 & 3.08 & 1.93 \\
\hline H-856/98 & 1.23 & 1.34 & 1.59 & 1.94 & 3.00 & 1.82 \\
\hline H-857/98 & 1.41 & 1.80 & 2.32 & 2.54 & 3.41 & 2.30 \\
\hline H-858/98 & 1.34 & 1.42 & 1.64 & 1.71 & 2.71 & 1.76 \\
\hline H-915/98 & 1.41 & 1.91 & 2.27 & 2.53 & 3.57 & 2.34 \\
\hline H-929/98 & 1.12 & 1.56 & 2.21 & 2.53 & 3.60 & 2.21 \\
\hline H-968/98 & 1.05 & 1.30 & 1.88 & 2.27 & 3.81 & 2.06 \\
\hline H-980/98 & 1.43 & 1.93 & 2.10 & 2.41 & 3.79 & 2.33 \\
\hline H-981/98 & 1.04 & 1.09 & 1.36 & 1.58 & 2.53 & 1.52 \\
\hline 74110 & 1.12 & 1.46 & 1.99 & 2.34 & 3.26 & 2.04 \\
\hline Mean & 1.25 & 1.56 & 1.96 & 2.25 & 3.33 & 2.07 \\
\hline C.V $(\%)$ & 19.00 & 28.80 & 27.50 & 5.80 & 21.00 & 21.50 \\
\hline LSD (0.05) & 0.39 & 0.75 & 0.90 & 0.97 & 1.16 & 0.74 \\
\hline
\end{tabular}




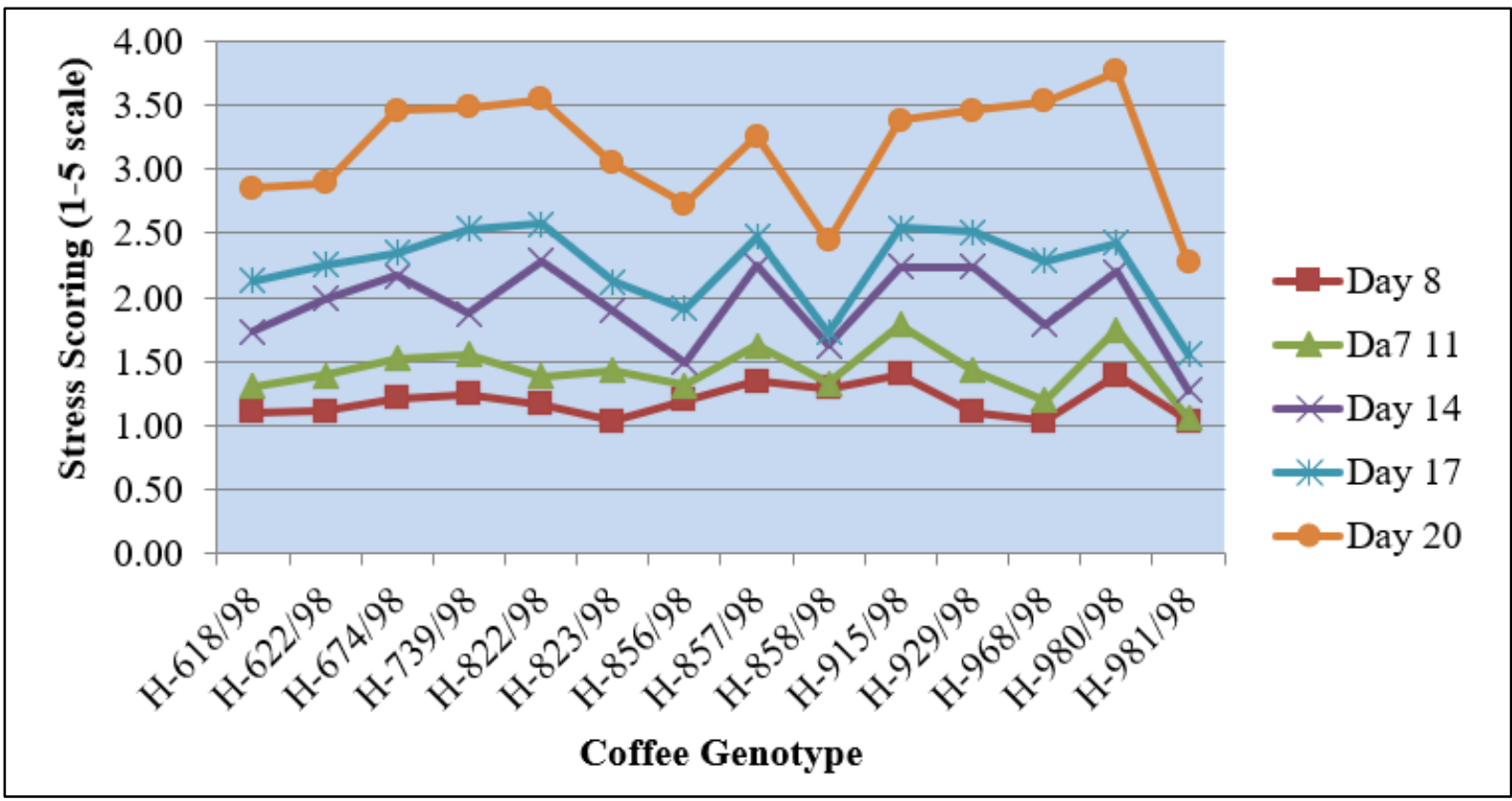

Figure 2. Morning stress score value for coffee genotypes under water-stressed (WS) condition on different days from start of treatment application

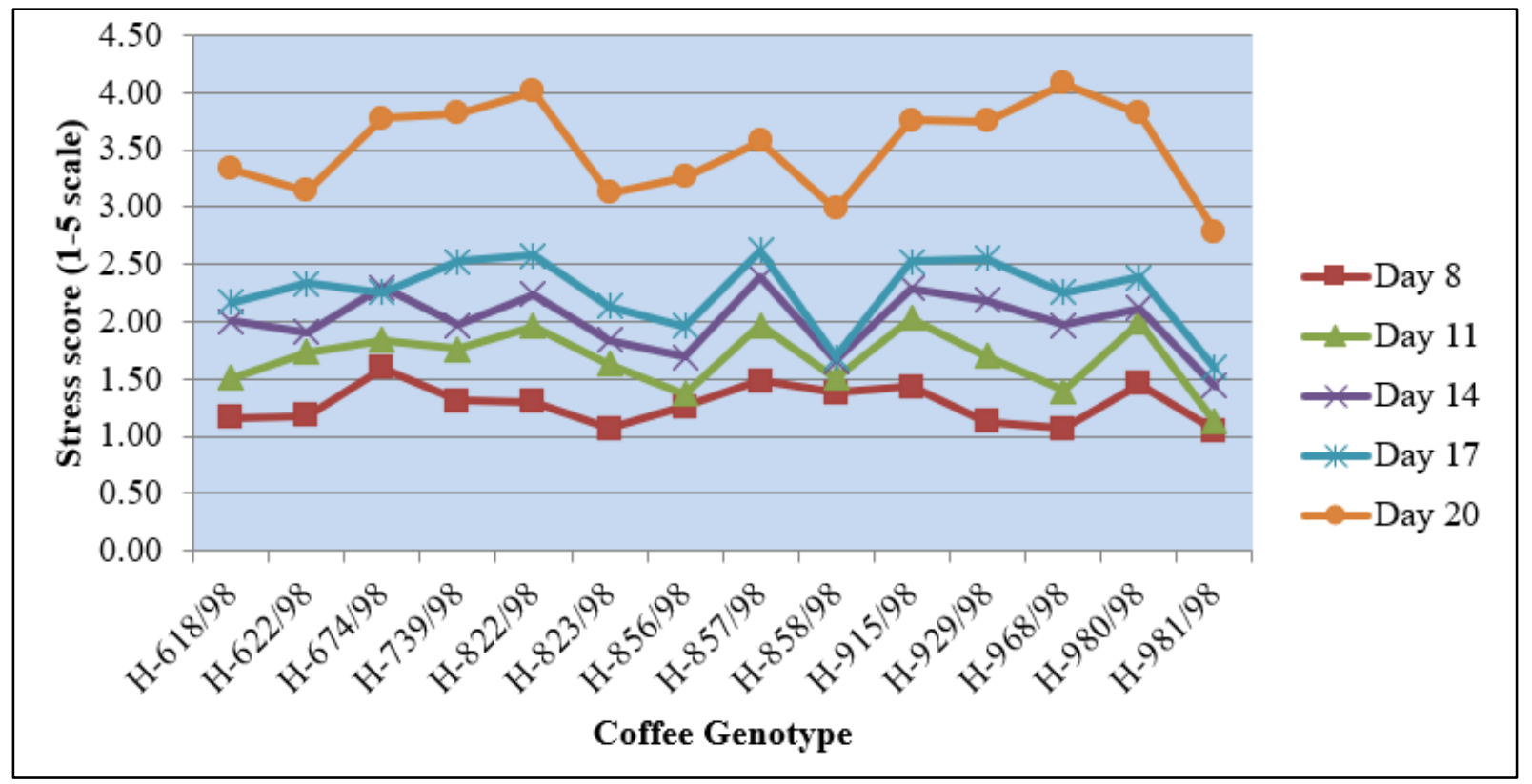

Figure 3. Noon stress score value for coffee genotypes under water-stressed (WS) condition on different days from start of treatment application

\section{Growth parameters of coffee plants under soil moisture deficit}

The results of analysis of variance showed significant difference among genotypes for sensitivity to water deficit stress period of 21 days for growth parameters (Table 2).
Accordingly, the highest plant height, larger girth and number of leaf were recorded from H-981/98 genotypes. Therefore, H-981/98 coffee genotype was more tolerant to water stress followed by H-980/98 genotypes than the rest of coffee genotypes (Table 2). 
Table 2. Early plant growth parameters of the coffee seedlings subjected to 21 days of water deficit stress

\begin{tabular}{ccccccccc}
\hline \multirow{2}{*}{ Genotypes } & \multicolumn{2}{c}{ Plant height (cm) } & \multicolumn{2}{c}{ Girth $\mathbf{( m m )}$} & \multicolumn{2}{c}{ Number of leaf } & \multicolumn{2}{c}{ Number of node } \\
\cline { 2 - 9 } & $\begin{array}{c}\text { Water } \\
\text { stressed }\end{array}$ & $\begin{array}{c}\text { Well } \\
\text { watered }\end{array}$ & $\begin{array}{c}\text { Water } \\
\text { stressed }\end{array}$ & $\begin{array}{c}\text { Well } \\
\text { watered }\end{array}$ & $\begin{array}{c}\text { Water } \\
\text { stressed }\end{array}$ & $\begin{array}{c}\text { Well } \\
\text { watered }\end{array}$ & $\begin{array}{c}\text { Water } \\
\text { stressed }\end{array}$ & $\begin{array}{c}\text { Well } \\
\text { watered }\end{array}$ \\
\hline H-618/98 & $32.30 \mathrm{a}$ & $39.33 \mathrm{abc}$ & $4.91 \mathrm{ab}$ & $5.97 \mathrm{bc}$ & 11.17 & 17.33 & 10.17 & 10.67 \\
H-622/98 & $41.93 \mathrm{~b}-\mathrm{e}$ & $42.95 \mathrm{~b}-\mathrm{e}$ & $5.06 \mathrm{abc}$ & $5.83 \mathrm{bc}$ & 14.83 & 22.50 & 10.00 & 10.33 \\
H-674/98 & $41.66 \mathrm{~b}-\mathrm{e}$ & $43.12 \mathrm{~b}-\mathrm{e}$ & $5.30 \mathrm{abc}$ & $5.56 \mathrm{~b}$ & 14.50 & 17.67 & 9.83 & 14.33 \\
H-739/98 & $40.10 \mathrm{a}-\mathrm{e}$ & $40.50 \mathrm{a}-\mathrm{d}$ & $5.28 \mathrm{abc}$ & $5.13 \mathrm{ab}$ & 11.33 & 23.83 & 10.33 & 11.33 \\
H-822/98 & $42.22 \mathrm{cde}$ & $45.33 \mathrm{de}$ & $4.83 \mathrm{ab}$ & $5.38 \mathrm{~b}$ & 15.33 & 23.17 & 9.67 & 11.00 \\
H-823/98 & $37.75 \mathrm{a}-\mathrm{d}$ & $37.00 \mathrm{a}$ & $5.48 \mathrm{a}-\mathrm{d}$ & $5.03 \mathrm{ab}$ & 13.25 & 17.33 & 9.87 & 11.33 \\
H-856/98 & $33.83 \mathrm{ab}$ & $37.65 \mathrm{ab}$ & $4.94 \mathrm{ab}$ & $5.10 \mathrm{ab}$ & 13.33 & 17.00 & 9.50 & 10.00 \\
H-857/98 & $34.23 \mathrm{abc}$ & $41.22 \mathrm{a}-\mathrm{d}$ & $5.37 \mathrm{abc}$ & $5.19 \mathrm{ab}$ & 12.50 & 19.17 & 9.17 & 9.83 \\
H-858/98 & $34.20 \mathrm{abc}$ & $38.77 \mathrm{abc}$ & $4.71 \mathrm{a}$ & $4.94 \mathrm{a}$ & 14.00 & 14.17 & 10.17 & 11.17 \\
H-915/98 & $36.07 \mathrm{a}-\mathrm{d}$ & $40.22 \mathrm{a}-\mathrm{d}$ & $4.74 \mathrm{a}$ & $5.34 \mathrm{~b}$ & 13.00 & 19.50 & 10.00 & 11.00 \\
H-929/98 & $39.42 \mathrm{a}-\mathrm{e}$ & $39.97 \mathrm{a}-\mathrm{d}$ & $5.94 \mathrm{bcd}$ & $5.80 \mathrm{bc}$ & 16.67 & 17.33 & 10.17 & 10.00 \\
H-968/98 & $42.92 \mathrm{de}$ & $43.78 \mathrm{cde}$ & $6.72 \mathrm{~d}$ & $6.88 \mathrm{c}$ & 14.50 & 19.50 & 10.50 & 11.50 \\
H-980/98 & $43.30 \mathrm{de}$ & $44.42 \mathrm{cde}$ & $5.92 \mathrm{bcd}$ & $5.97 \mathrm{bc}$ & 13.83 & 20.67 & 9.67 & 13.33 \\
H-981/98 & $46.42 \mathrm{e}$ & $48.03 \mathrm{e}$ & $6.11 \mathrm{~cd}$ & $6.18 \mathrm{bc}$ & 14.00 & 25.33 & 9.67 & 11.33 \\
74110 & $35.72 \mathrm{a}-\mathrm{d}$ & $40.75 \mathrm{a}-\mathrm{d}$ & $5.14 \mathrm{abc}$ & $6.03 \mathrm{bc}$ & 17.33 & 25.33 & 9.83 & 10.17 \\
\hline Mean & 38.80 & 41.54 & 5.36 & 5.56 & 3.99 & 19.99 & 9.89 & 11.16 \\
LSD $(5 \%)$ & 8.25 & 5.92 & 1.18 & 1.26 & 5.96 & 7.16 & 1.80 & 3.27 \\
CV \% & 12.80 & 8.50 & 13.00 & 13.60 & 25.10 & 21.50 & 10.90 & 17.60 \\
\hline
\end{tabular}

\section{Tap root length and root volume}

Table 3. Tap root length and root volume as affected by soil moisture deficit after 21 days of stress period

\begin{tabular}{ccccc}
\hline \multirow{2}{*}{ Accessions } & \multicolumn{2}{c}{ Tap root length (cm) } & \multicolumn{2}{c}{ Root volume (ml) } \\
\cline { 2 - 5 } & $\begin{array}{c}\text { Water } \\
\text { Stressed }\end{array}$ & $\begin{array}{c}\text { Well } \\
\text { Watered }\end{array}$ & $\begin{array}{c}\text { Water } \\
\text { Stressed }\end{array}$ & $\begin{array}{c}\text { Well } \\
\text { Watered }\end{array}$ \\
\hline H-618/98 & $17.97 \mathrm{a}-\mathrm{d}$ & 23.42 & 8.50 & 11.50 \\
H-622/98 & $15.13 \mathrm{ab}$ & 18.43 & 9.33 & 19.67 \\
H-674/98 & $18.57 \mathrm{a}-\mathrm{e}$ & 20.98 & 8.67 & 19.00 \\
H-739/98 & $16.3 \mathrm{abc}$ & 18.17 & 8.33 & 21.33 \\
H-822/98 & $16.97 \mathrm{a}-\mathrm{d}$ & 15.09 & 8.33 & 15.33 \\
H-823/98 & $21.67 \mathrm{de}$ & 21.07 & 9.17 & 15.17 \\
H-856/98 & $15.73 \mathrm{abc}$ & 21.03 & 8.00 & 16.17 \\
H-857/98 & $23.87 \mathrm{e}$ & 19.43 & 8.83 & 12.17 \\
H-858/98 & $21.07 \mathrm{cde}$ & 22.92 & 5.33 & 9.33 \\
H-915/98 & $14.37 \mathrm{a}$ & 16.97 & 7.17 & 12.17 \\
H-929/98 & $19.17 \mathrm{a}-\mathrm{e}$ & 21.48 & 7.83 & 16.33 \\
H-968/98 & $15.63 \mathrm{ab}$ & 18.43 & 8.33 & 14.83 \\
H-980/98 & $17.97 \mathrm{a}-\mathrm{d}$ & 21.48 & 9.83 & 18.50 \\
H-981/98 & $20.03 \mathrm{~b}-\mathrm{e}$ & 16.55 & 10.00 & 14.83 \\
74110 & $19.30 \mathrm{a}-\mathrm{e}$ & 18.93 & 4.67 & 7.50 \\
\hline Mean & 18.25 & 9.63 & 8.16 & 14.92 \\
LSD $(5 \%)$ & 5.35 & 5.02 & 5.39 & 8.86 \\
CV \% & 17.6 & 15.3 & 39.6 & 35.6 \\
\hline
\end{tabular}

There was significant differences among coffee genotypes for sensitivity to water deficit stress, for tap root length. However, non-significant differences for root volume (Table 3). Tap root length was significantly affected by water stress period of 21 days with the longest $(23.87 \mathrm{~cm})$ tap root length recorded from genotype H-857/98. While the lowest $(14.37 \mathrm{~cm})$ tap root length was recorded from H-915/98 coffee genotype. This indicates that plant water stress developed more slowly in the drought-tolerant genotypes than in the drought-sensitive genotypes. In agreement with this finding, studies on Robusta coffee showed deeper root system (Pinheiro et al., 2005) and larger root dry mass in drought tolerant clones than in drought sensitive ones (DaMatta and Ramalho, 2006).

\section{Relative Water Content of leaf}

The present study revealed that there was no significant difference among genotypes for relative leaf water contents. From the result, all the coffee genotypes showed an average relative water content ranging from 34\% (H-980/98) - 57.77\% (H-857/98) under water stress (Table 4). The lower rate of stress development coupled with higher plant water status (as the case with genotypes H-857/98 and H-929/98) or lower value for both parameters (such as in genotype in accession H-981/98) could be attributed to some drought tolerance mechanisms such as osmotic adjustment, which maintain turgidity of leaves, despite the water stress (Tesfaye, 2005). On the 
other hand, maintenance of plant water status at higher level with relatively severs leaf folding and wilting symptoms could also be regarded as one of the drought avoidance strategies in crop plant (Wiersma and Christie, 1987; Davies et al., 2000, Tesfaye 2005; Tesfaye and Ismail, 2008).

\section{Leaf Area and Specific Leaf Area}

There were significant differences among coffee genotypes on sensitivity to water stress, as evaluated by mean values of visual Specific Leaf Area. Leaf area and specific leaf area of coffee genotypes fell in the range between 73.88 and 44.12 to 1.07 and 27.36 , respectively. Two genotypes; H-822/98 and H-981/98 had exhibited low specific leaf area. Whereas the highest mean value of specific leaf area was recorded from $\mathrm{H}-823 / 98$ andH-622/98 genotypes (Table 4). Similarly low mean value of leaf area had recorded in H-980/98 genotype, while the highest mean value of leaf area had observed from 74110 varieties followed by H-739/98 genotype
(Table 4). The significant difference observed among coffee genotypes for leaf area and leaf specific area have been reported by some authors. DaMatta and Ramalho (2006) reported coffee genotypes have been found to differ in drought adaptation mechanisms such as stomata control and soil water extraction efficiency.

\section{Rate of Recovery Plant After Stressed}

It was observed that there was significant difference between the coffee genotypes for rate of recovery after rewarding. Generally, all the genotypes recovered well except three genotypes; H-822/98, H-968/98 and H-980/98 after resuming irrigation (Table 4). In line with this Moore (1987) has reported that plant recovery ability after drought is more important than drought tolerance. This observation is also in agreement with the finding of Sundara (1987), who reported that recovery can be rapid, with normal growth resumed, if moisture stress has not adversely affected plant biomass and root growth.

Table 4. Means of relative water content (RWC), leaf area (LA), specific leaf area (SLA), Rate of leaf shade (RLSH), Rate of recovery plant (RRP) of coffee genotypes under water stress (WS) conditions

\begin{tabular}{|c|c|c|c|c|c|}
\hline Genotypes & RWCL & $\mathbf{L A}$ & SLA & RRP & RLSH \\
\hline H-618/98 & 54.92 & $64.02 \mathrm{a}$ & $18.98 \mathrm{ab}$ & $23.96 \mathrm{abc}$ & $82.58 \mathrm{a}$ \\
\hline H-622/98 & 49.90 & $60.80 \mathrm{a}$ & $27.36 \mathrm{a}$ & $27.08 \mathrm{abc}$ & $79.97 \mathrm{ab}$ \\
\hline H-674/98 & 52.89 & $64.16 \mathrm{a}$ & $14.10 \mathrm{ab}$ & $21.08 \mathrm{abc}$ & $54.99 \mathrm{abc}$ \\
\hline H-739/98 & 53.31 & $68.42 \mathrm{a}$ & $14.14 \mathrm{ab}$ & $15.13 \mathrm{abc}$ & $71.38 \mathrm{abc}$ \\
\hline H-822/98 & 42.16 & $62.16 \mathrm{a}$ & $7.65 \mathrm{~b}$ & $5.75 \mathrm{c}$ & $37.15 \mathrm{c}$ \\
\hline H-823/98 & 54.42 & $65.69 \mathrm{a}$ & $25.34 \mathrm{a}$ & $17.25 \mathrm{abc}$ & $40.79 \mathrm{bc}$ \\
\hline H-856/98 & 50.3 & $64.45 \mathrm{a}$ & $17.70 \mathrm{ab}$ & $24.50 \mathrm{abc}$ & $38.63 \mathrm{c}$ \\
\hline H-857/98 & 57.77 & $58.92 \mathrm{ab}$ & $24.35 \mathrm{a}$ & $16.71 \mathrm{abc}$ & $56.89 \mathrm{abc}$ \\
\hline H-858/98 & 53.75 & $58.63 \mathrm{ab}$ & $19.48 \mathrm{ab}$ & $35.42 \mathrm{a}$ & $51.42 \mathrm{abc}$ \\
\hline H-915/98 & 54.35 & $59.62 \mathrm{a}$ & $21.51 \mathrm{ab}$ & $16.67 \mathrm{abc}$ & $72.74 \mathrm{abc}$ \\
\hline Н-929/98 & 54.49 & $64.05 \mathrm{a}$ & $22.65 \mathrm{ab}$ & $15.63 \mathrm{abc}$ & $61.35 \mathrm{abc}$ \\
\hline H-968/98 & 55.45 & $63.12 \mathrm{a}$ & $23.13 \mathrm{a}$ & $4.71 \mathrm{c}$ & $49.42 \mathrm{abc}$ \\
\hline H-980/98 & 34.32 & $44.12 \mathrm{~b}$ & $16.72 \mathrm{ab}$ & $7.33 \mathrm{bc}$ & $89.86 \mathrm{a}$ \\
\hline H-981/98 & 57.44 & $61.69 \mathrm{a}$ & $1.07 \mathrm{~b}$ & $29.21 \mathrm{ab}$ & $80.61 \mathrm{ab}$ \\
\hline 74110 & 53.88 & $73.88 \mathrm{a}$ & $22.69 \mathrm{ab}$ & $26.63 \mathrm{abc}$ & $59.32 \mathrm{abc}$ \\
\hline Mean & 52.34 & 62.25 & 19.27 & 19.14 & 11.03 \\
\hline CV (\%) & 22.25 & 14.79 & 47.73 & 71.93 & 59.56 \\
\hline
\end{tabular}

Note: RWCL relative water content of leaf, LA leaf area, SLA specific leaf area, RLSH Rate of leaf shade, RRP Rate of recovery plant 


\section{Conclusions and Recommendation}

Generally, the study results indicated the presence variation among Arabica coffee genotypes for sensitivity to water stress. Based on preliminary observations and visual assessments of recovery plants, the genotypes were grouped into three categories of drought tolerance; sensitive, moderately sensitive and relatively tolerant. Accordingly, two coffee genotypes; H-981/98 and H-858/98 showed superior for water stress tolerance than other genotypes and varieties. Therefore, genotypes from each category should also be tested for their morphological, physiological and biochemical responses to drought in order to identify more tolerant types and come up with a recommendation for further selection and breeding program for drier coffee growing areas.

\section{REFERENCES}

[1] Adam, F. and S.S. Barakbah. 1990. Response to Water stress in Banana, peanut and Rice: A comparative study. Transactions of Malaysian Soc. Plant Physiol. 1(1990): 99-104.

[2] Alam, S.M. 1999. Nutrient Uptake by Plants under Stress Conditions. In: M. Pessarakli (ed.).Handbook of Plant and Crop Stress. Second Ed., Revised and Expanded. Marcel Dekker, Inc., New York. Pp.285-313.

[3] Arndt, S.K.; Wanek, W.; Clifford, S.C. and M. Popp. 2000. Contrasting adaptations to drought stress in field-grown Ziziphuns mauritiana and Prunus persica trees: water relations, osmotic adjustment and carbon isotope composition. Australian Journal of Plant Physiology 27: 985-996.

[4] Barros, R.S.; da S.E. Mota, J.W.; Damatta, F.M. and Maestri, M. 1997. Decline of vegetative growth in Coffea arabica L. in relation to leaf temperature, water potential and stomatal conductance. Field Crops Research 54: 65-72.

[5] Burkhardt J Bowyer, P., and Danson, F.M. (2004). Sensitivity of spectral reflectance to variation in live fuel moisture content at leaf and canopy level, Remote sensing of Environment, 92 (3), 297-308.

[6] Beining A, Kufa T, Goldbach HE (2006). Different drought adaptation strategies of Coffea arabica populations along a rainfall gradient in Ethiopia. In: Asch F, Becker M (eds) Prosperity and Poverty in a Globa ised World - Challenges for Agricultural Research. Tropentag, Bonn, Germany.

[7] Carr, M.K.V., 2001. The Water Relations and Irrigation Requirements of Coffee. Exp. Agric., 37: 1-36

[8] Carter, T.E., Jr. and T.W. Rufty. 1992. Soybean plant introduction Exhibiting Drought and Aluminum Tolerance. In: C.G. Kuo (Ed.), Adaptation of food crops to temperature and water stress. Proceedings of an international symposium, Taiwan, 13-18 August 1992. Asian Vegetable Research and Development center (AVRDC), Shanhua, and Taiwan. Pp.335-346.
[9] Cutler, J.M.; Shahan, K.W. and P.L. Steponkus. 1980 Dynamics of osmotic adjustment in rice. Crop Sci. 20: 210 314

[10] DaMatta FM (2004). Ecophysiological constraints on the production of Shaded and unshaded coffee: A review. Field Crops Research 86: 99-114.

[11] De Datta, S.K.; Malabuyoc, J.A. and E.L. Aragon. 1988. A field screening technique for evaluating rice germplasm for drought tolerance during the vegetative stage. Field Crops Res. 19: 123 - 134

[12] De Souza J.G., Da Silv J.V. (1987) Partitioning of carbohydrates in annual and perennial cotton (Gossypium hirsutum L.), J. Exp. Bot. 38, 1211-1218)

[13] Dias PC, Araujo WL, Moraes GABK, Barros RS, DaMatta FM (2007). Morphological and physiological responses of two coffee progenies to soil water availability. J. Plant. Physiol., 164: 1639-1647

[14] Ginter-Whitehouse, D.L.; Hinckley, T.M. and S.G. Pallardy. 1983. Spatial and temporal aspects of water relations of three tree species with different vascular anatomy. For. Sci. 29: $317-329$

[15] Itai, C. and L.G. Paleg. 1982. Responses of water-stressed Hordeum distichum L. and Cucumis sativus to proline and betaine. Plant Science Letters 25: 329 - 335.

[16] Joshi, A.K. 1999. Genetic factors affecting abiotic stress tolerance in crop plants. In Handbook of Plant and Crop Stress, ed. M. Pessarakli, pp 795 - 826. New York: Marcel Dekker.

[17] Karpinski, S.; Reynolds, H.; Karpinska, B.; Wingsle, G.; Creissen, G. and P. Mullineaux. 1999. The role of hydrogen peroxide and antioxidants in systemic acclimation to photo-oxidative stress in Arabidopsis. In Plant Responses to Environmental Stress, ed. M.F. Smallwood, C.M. Calvert and D.J. Bowles, pp 25 - 32. Oxford: BIOS Scientific Publishers.

[18] Kassahun Tesfaye, Tamiru Oljira, Kim Govers, Endashaw Bekele and Thomas Borsch. 2008. Genetic Diversity and Population Structure of Wild Coffea arabica Populations in Ethiopia Using Molecular Markers. In: Girma A., Bayetta B., Tesfaye S., Endale T. and Taye K. (Eds.). Coffee Diversity and Knowledge. Proceedings of a National Workshop: Four Decades of Coffee Research and Development in Ethiopia. 14 - 17 August, 2007. Addis Ababa, Ethiopia. Pp. 35 - 44.

[19] Kitbamroong, C. and Y. Chantachume. 1992. Corn improvement for Drought Tolerance. In: C.G. Kuo (Ed.), Adaptation of food crops to temperature and water stress. Proceedings of an international symposium. Taiwan, 13-18 August 1992. Asian Vegetable Research and Development Center (AVRDC), Shanhua, Taiwan. Pp.354-359.

[20] Kramer PJ, Boyer JS (1995). Water relations of plants and soils. San Diego: Academic Press.

[21] Kozlowski, T.T. and S.G. Pallardy. 1997. Physiology of woody plants. $2^{\text {nd }}$ Edn. San Diego: Academic Press.

[22] Kufa T, Burkhardt J (2011). Stomatal characteristics in Arabica Coffee Germplasm Accessions under contrasting environments at Jimma, Southwestern Ethiopia. International Journal of Botany 7 (1): 63-72 
[23] Lawlor, D.H. 1995. The effects of water deficit on photosynthesis. In Environment and plant metabolism-flexibility and acclimation, ed. N. Smirnoff, pp 129 - 156. Oxford: BIOS Scientific Publishers.

[24] Levitt, J.1980. Responses of plants to environmental stresses, Vol. 2, Water, Radiation, Salt, and Other Stresses. New York: Academic Press.

[25] Lilley, J.M. and S. Fukai. 1994. Effect of timing and severity of water deficit on four diverse rice cultivars II. Physiological responses to soil water deficit. Field Crops Research 37: 215 - 223.

[26] Lima, A.L.S.; DaMatta, F.M.; Pinheiro, H.A.; Totola, M.R. and Loureiro, M.E. 2002. Photochemical responses and oxidative stress in two clones of Coffea canephora under water deficit conditions. Environmental and Experimental Botany 47: 239-247.

[27] Loewenstein, N. J. and S.G. Pallardy.1998a. Drought tolerance, xylem sap abscisic acid and stomatal conductance during soil drying: a comparison of young plants of four temperate deciduous angiosperms. Tree physiology 18: 421-430.

[28] Loewenstein, N.J. and S.G. Pallardy.1998b. Drought tolerance, xylem sap abscisic acid and stomatal conductance during soil drying: a comparison of canopy trees of three temperate deciduous angiosperms. Tree Physiology 18: 431-439.

[29] Ludlow, M.M. and R.C. Muchow. 1990. A critical evaluation of traits for improving crop yields in water-limited environments. Advances in Agronomy 43: 107 $-153$

[30] Maestri, M.; Da Matta, F.M.; Regazzi, A.J. and R.S. Barros. 1995. Accumulation of proline and quaternary ammonium compounds in mature leaves of water stressed coffee plants (Coffea Arabica and C. canephora). J. Hort. Sci. 70: $229-$ 233

[31] Martin, U.; Pallardy, S.G. and Z.A. Bahari. 1987. Dehydration tolerance of leaf tissues of six woody angiosperm species. Physiol. Plant. 69: $182-186$.

[32] Meinzer, F.C.; Grantz, D.A.; Goldstein, G. and N.Z. Saliendra. 1990. Leaf water relations and maintenance of gas exchange in coffee cultivars grown in drying soil. Plant Physiol. 94: 1781 - 1787.

[33] Melaku Werede. 1982. Coffee Berry Disease in Ethiopia: A Country Report. Proceedings of the First Regional Workshop on Coffee Berry Disease. Addis Ababa, Ethiopia. Pp. $71-95$.

[34] Morgan, J.M.1984. Osmoregulation and water stress in higher plants. Annu. Rev. Plant Physiol. 35: 299-319.

[35] Nambiar, E.K.S.; Cotterill, P.P. and G.D. Bowen. 1982. Genetic differences in the root regeneration of radiata pine. $J$. Exp. Bot. 33: 170 - 177.

[36] Navari-Izzo, F. and N. Rascio. 1999. Plant Response to Water-Deficit Conditions. In Handbook of Plant and Crop Stress, ed. M. Pessarakli, pp 231-270. New York: Marcel Dekker.

[37] Patakas, A.; Radoglou, K. and B. Noitsakis. 2002. The role of organic solute and ion accumulation in osmotic adjustment in drought-stressed grapevines. Plant science 00(2002)1-7. Accessed June, 2002.

[38] Price, M.; Jalaluddin, Md. And R.H. Dilday. 1992. Evaluation of Rice Germplasm for Drought Tolerance. In: C.G. Kuo (Ed.), Adaptation of food crops to temperature and water stress. Proceedings of an international symposium, Taiwan, 13-18 August 1992. Asia Vegetable Research and Development center (AVRDC), Shanhua, Taiwan. Pp. 347-353.

[39] Pugnaire, F.I.; Serrano, L. and J.Pardos. 1999. Constraints by Water Stress on Plant Growth. In Handbook of Plant and Crop Stress, ed. M. Pessarakli, pp 271-283. New York: Marcel Dekker.

[40] Rena, A.B.; Barros, R.S; Maestri, M. and M.R. Sondahl. 1994. Coffee. In Handbook of Environmental Physiology of Fruit Crops, Vol. 2, Sub-Tropical and Tropical Crops, ed. B. Schaffer and P.C. Andersen, pp 101 - 122. Boca Raton, Florida: CRC Press.

[41] Rosario, D.A.; Ocampo, E.M.; Sumague, A.C. and M.C.M. Paje. 1992. Adaptation of vegetable Legumes to drought stress. In: C.G. Kuo (Ed.) Adaptation of food crops to temperature and water stress. Proceedings of an international symposium, Taiwan, 13-18 August 1992. Asian Vegetable Research and Development Center (AVRDC), Shanhua, Taiwan. Pp.360-371.

[42] Sanchez, F.J.; Manazanares, M.; de Andres, E.F.; Tenorio, J.L. and L. Ayerbe. 1998. Turgor maintenance, osmotic adjustment and soluble sugar and proline accumulation in 49 pea cultivars in response to water stress. Field Crops Research 59:225-235.

[43] Sloane, R.J.; Patterson, R.P. and T.E.Jr. Carter. 1990. Field drought tolerance of a soybean plant introduction. Crop Sci. 30: $118-123$.

[44] Smirnoff, N. 1995. Antioxidant systems and plant response to the environment. In Environment and plant metabolism-flexibility and acclimation, ed. N. Smirnoff, pp 217 - 243. Oxford: BIOS Scientific Publishers.

[45] Siamak, S. B., Sariah,M., Zakaria,W., Sreeramanan, S. and Maziah,M. 2012. In vitro selection and characterization of water stress tolerant lines among ethyl methanesulphonate (EMS) induced variants of banana (Musa spp., with AAA genome). Australian Journal of Crop Science 6(3):567-575.

[46] Tesfaye, S.G., 2005. Growth, water relations, yield and crop quality of Arabica coffee in response to water stress and deficit irrigation. Ph. D. Dissertation, University Putra Malaysia, Malaysia

[47] Tesfaye S.; Alemseged Y.; Taye K.; Endale T. and Anteneh N. 2006. Coffee seedling management and production (Handbook, Amharic version). Ethiopian Agricultural Research Organization, 2006. Addis Ababa, Ethiopia. 17 p.

[48] TESFAYE SHIMBER and M.R. ISMAIL. 2008. Variability among indigenous Arabica coffees for drought tolerance under controlled environment.

[49] Girma A., Bayetta B., Tesfaye S., Endale T. and Taye K. (Eds.). 2008. Coffee Diversity and Knowledge. Proceedings of a National Workshop: Four Decades of Coffee Research and Development in Ethiopia. 14 - 17 August, 2007. Addis Ababa, Ethiopia. Pp. 150 - 157. 
[50] Tesfaye S. G.; M. R. Ismail; M. F. Ramlan.; M. Marziah And H. Kausar. 2013. Effect of Soil Drying on Rate of Stress Development, Leaf Gas Exchange and Proline Accumulation in Robusta Coffee (Coffea Canephora Pierre Ex Froehner) Clones. Expl Agric.: page 1 of 22 Cambridge University Press 2013. Pp. 1 - 22.

[51] Tesfaye S.G., M.R. Ismail, M.F. Ramlan, M. Marziah, H. Kausar and M.A. Hakim. 2015. Effect of water deficiency on growth and dry matter yield of selected Robusta coffee (Coffea canephora) clones in Malaysia. Journal of Environmental Biology. Vol.36, No 5: PP. 1239-1245.
[52] Turner, N.C. 1990. Plant water relations and irrigation management. Agric. Water Manage. 17: 59 - 73. Volkmar, K.M. and Woodbury, W. 1995. Plant-water Relationships. In Handbook of plant and crop physiology, ed. M. Pessarakli, pp 23-43. New York: Marcel Decker, Inc.

[53] Yacob, E.; Tesfaye, S.G.; Alemseged, Y.; Taye, K; Anteneh, N.; Takele, N.; Mohammed, A.C. and B. Bogale. 1996. Advances in coffee agronomy research in Ethiopia. In: Improving Coffee Management Systems in Africa. Proceedings of IACO workshop, 4 - 6 September, 1995, Kampala, Uganda. The African Crop Science Society. Pp. $40-55$. 